\title{
WORKING THE SECOND SHIFT, SETTLING IN CANADA AND OTHER STRUGGLES; NARRATIVES OF WORKING AFRICAN- IMMIGRANT MOTHERS IN TORONTO.
}

\author{
By \\ Muno Mohamed Osman, BSW, Carleton University, 2012 \\ A Major Research Paper \\ Presented to Ryerson University \\ in partial fulfillment of the requirements for the degree of \\ Master of Social Work \\ in the Program of \\ Social Work
}

Toronto, Ontario, Canada, 2014

(C) Muno Mohamed Osman 2014 


\section{AUTHOR'S DECLARATION}

I hereby declare that I am the sole author of this MRP. This is a true copy of the MRP, including any required final revisions.

I authorize Ryerson University to lend this MRP to other institutions or individuals for the purpose of scholarly research

I further authorize Ryerson University to reproduce this MRP by photocopying or by other means, in total or in part, at the request of other institutions or individuals for the purpose of scholarly research.

I understand that my MRP may be made electronically available to the public. 


\title{
WORKING THE SECOND SHIFT, SETTLING IN CANADA AND OTHER STRUGGLES; NARRATIVES OF WORKING AFRICAN- IMMIGRANT MOTHERS IN TORONTO.
}

\author{
Master of Social Work, 2014 \\ Muno Mohamed Osman \\ Program of Social Work, \\ Ryerson University
}

This research study explores the experiences of working African immigrant mothers in accessing formal childcare services in Toronto. I start the study with an over view of the literature on the topics of access to childcare service and women's labour force participation. I then review social reproduction and black feminist theories; the theoretical framework for my research. I also highlight the current state of childcare in Canada and how this affects African immigrant mothers who work. The study includes qualitative in-depth interviews with four such mothers who talk about their challenges and experiences in balancing work and family responsibilities in Toronto. The study found that the mothers are dissatisfied with several aspects of the childcare services they use or have used in the past. The mothers also face many struggles owing to patriarchal gender norms in their households and loss of extended family supports after immigration.

Key Words: Formal child-care, immigrant, women, labour-force participation, work, African mothers. 


\section{ACKNOWLEDGEMENTS}

I would like to take this opportunity to acknowledge my MRP supervisor Dr. Henry Parada, for his support and guidance throughout the eleven-month period it took to conceive, develop and complete this study. Thank you for the re-reads, the suggestions, the comments and the motivation you offered to help me write the best possible MRP I could. I am grateful for all your help.

I would also like to offer my gratitude to my second reader, DR Benjimin Akua, whose keen and knowledgeable eye helped me review the final draft of this paper. Your constructive criticism and comments have greatly improved my paper and I am grateful for them.

I am sincerely grateful to the four women who shared their stories with me and who have allowed me to get a glimpse into their lives. I am honoured to pass on your stories and I will forever remain inspired by your hard work, strength and devotion to your families.

Many dear friends have been there to give me physical and moral support through out the processes of this paper. Special thanks go to; Dionisio Nyaga, Fartun Abdirahaman, Hermon Rezene, Sadia Mohamed, Sahro Osman, Sofia Alexandra, Phil Mach and Zamzam Elmi. Thank your for everything you did to help make this dream a reality.

My heartfelt gratitude goes to my parents and sisters for their unwavering support throughout my seventeen-year long academic journey. Your love has always being my greatest strength and has helped me reach many milestones including the end of this research process. Thank you for always believing in me and for encouraging me to do my best.

Finally, thanks to my beloved husband, Abdullahi Osman. Your faith in me as well as your endless support has being invaluable in completing this Masters degree and this MRP. Thank you for being the greatest blessing of my life. 


\section{DEDICATION}

This MRP is dedicated to three generations of women in my family:

To my Mother Safiya Abdikadir Farah; for your unparalleled love and devotion, for giving my sisters and I the academic opportunities you were denied as a young girl and for installing in us the value of being strong, hardworking and courageous women.

For my sisters' daughters, my nieces Rayaan and Ruweyda Ahmed; May you always know your worth as girls, as women. May you realize your potential with out any limits. 


\section{Table of Contents}

I. Introduction 1

i. Self-Reflection 3

II: Literature Review $\quad 5$

$\begin{array}{ll}\text { i. Theoretical Frameworks } & 16\end{array}$

III. Methodology 24

IV. Findings 31

i. Challenges from the State of Childcare System in Toronto 36

ii. Childcare- Women's Work 40

iii. Immigration and loss of Extended Family Support 43

$\begin{array}{ll}\text { V. Analysis } & 46\end{array}$

i. Challenges from the State of the Childcare System in Toronto 46

ii. Caring for Children and other women's work 51

iii. Immigration $\quad 55$

$\begin{array}{ll}\text { VI. Conclusion } & 57\end{array}$

$\begin{array}{lr}\text { VII. Appendices } & 59\end{array}$ 


\section{LIST OF APPENDICES}

Appendix A - Interviewed guide Questions

Page 59

Appendix B - Information and consent form

Page 60-63 


\section{Introduction}

This MRP is focused on exploring the experiences of African immigrant mothers who have used formal childcare services in Toronto while they worked. Formal or licenced child-care service in Ontario refers to home-based or day-care centre based childcare arrangements regulated by law to meet specific standards (Child care in Ontario, 2011). Previous research on labour force participation shows that Immigrant women in Canada are over represented in the unemployment and underemployment statistic and often face a number of barriers to successful labour force participation (Skinner, 2009). Some of this research identifies the lack of affordable and quality childcare services as one of the major barriers to labour force participation of mothers (Hill, 2011; Skinner 2009). In this MRP, mothers are considered to be participating the labour force if they have a paid employment whether part-time or full time. Due to high rates of poverty among immigrants and the feminization of precarious employment and poverty, immigrant mothers are at a higher disadvantage when it comes to the numerous challenges they face in their efforts to secure enjoyable and stable employment (Frankowicz, 2007).

The state of childcare service provision in Canada has been debated and addressed by feminist scholars, academics and child care activists alike. In all of this literature, childcare is lauded as the backbone of family policy and as an important factor in children's development as well as women’s equality issue (Albanese, P. 2006; Cleveland et al, 2008; Prentice, 2007 \& Friendly, 2009). A smaller number of scholars have also addressed the childcare access experiences of refugee and immigrant women and the related challenges immigrant women face due to the lack of affordable, high quality child care (Morantz et al, 2012; Skinner, 2009; Frankwociz, 2007). While the background literature and theories informing this MRP come from 
a wide array of disciplines, feminist literature on intersectionality and social reproduction theory on social care form the basis for this research.

The structure of this MRP starts with a literature review that highlights the issues introduced above including women's increased labour force participation, new-comer working mothers' specific challenges in accessing childcare, as well as in the lack of adequate government supports for childcare service provision in Canada. The literature review also addresses what the scholars have written about the quality and quantity of childcare arrangements available in Toronto/Ontario and how this affects families. The literature review chapter also provides an overview of black feminist and social reproduction theories; the two main theories used to analyse the data from this research. Providing this overview is necessary in order to give a background for understanding this research and to explain why these theories were considered the right framework to understand the experiences of the mothers who participated in this study. In the methodology section of the MRP, the research design for data collection and analysis is explained before the findings of the study are presented in the next section. Lastly, the practice and research implications of these findings will be examined in the analysis section before this MRP concludes with recommendations for further research.

This MRP has explored the narratives of four African immigrant mothers who talk about their experiences of accessing childcare services in Toronto while participating in the labour force. In order to recruit for this study, a non-probability sampling method was used to find African-immigrant mothers who have experienced the use of formal childcare services while working. In the study, qualitative in-depth interviews were conducted with the participants and the topics explored include the participants' experiences with the current formal childcare system in Toronto, the effect of traditional gender roles in their families and how the reality of 
immigration factors into these experiences. The aim of this study is to provide exploratory information of the real life daily experiences of this group of women whose voices are underrepresented in the research on childcare access and labour force participation.

\section{i. Self-Reflection}

Coming from an anti-oppressive social work and feminist backgrounds, I feel that it is necessary to engage in self-reflection around why I chose to explore this topic as well as how my social location affects this study and issues explored below. My interest in the relationship between motherhood and labour force participation started relatively earlier in life when I would often hear about women's choice between having a career and a family. As someone who identified as a feminist from a young age, I was opposed to the idea that motherhood limits a woman's potential in life and always believed that I could have a family and a career at the same time. However, upon a closer observation of the current political and economic environment in Canada and how it puts mothers in an uncomfortable position of trade-offs, I was not so sure about my future aspirations. Women often have to face trade-offs that involve having to choose between becoming a mother and being able to participate in the labour force to earn their own income. As an immigrant woman who has fought hard to achieve higher education and who also hopes to be a mother sometime in the near future, I am personally invested in the creation of an affordable, quality childcare service for all mothers. This personal connection or what Willet (2005) calls "having a stake in the research" is extremely important in doing social justice research and helps keep researchers accountable.

This topic is also of professional interest to me since social workers have an obligation to work for improving the quality of life for all members of society and have to work towards a 
more just and equitable society (Canadian Association of Social workers, 2005). Anti-oppression social work is concerned with the ways in which oppressive system in society marginalize certain individuals and groups in society. Feminism is particular concerned in the ways that sexism in particular marginalizes women and gives them less power. For these reasons research based on anti-oppressive and feminist values are important in exploring a study such as this one in order to inform doing anti-oppressive, transformative social work. The fact that patriarchal family and state systems makes mothers' labour force participation difficult/impossible and that Africa-immigrant mothers face further challenges in due to racism and immigration status has many implication for both anti-oppressive social work practice and research.

While I am an African-immigrant women who belongs to the community that is the target of this research, it is also important for me to understand that other issues of social location separate me from some of the participants of this research. The fact that I am not a mother yet and that I have had the privilege of accessing higher education might have created a gulf between myself and some of the research participants of this research. In this regard, I utilised Humphrey’s (2007) discussion of researcher’s insider/outside positionality as a guide to being aware of these differences and figure our strategies to build a relationship that can transcend these difference. 


\section{II: Literature Review}

Canada does not have a national childcare policy despite many decade-long campaigns and struggle for a universal childcare program. After many years of advocacy and negotiations, a national childcare program appeared to be on the horizon when bilateral agreements between the federal government and the provinces/territories were almost finalized in early 2006. However, upon their 2006 election, the federal conservative government cancelled all plans for the budding national childcare program announcing the 100\$ Universal Child Care Benefit instead (Friendly \& Ferns 2014). Currently licensed childcare in Canada is provincially regulated, underfunded and is generally in a patchwork (Broad and Foster, 2003; Friendly and Hennessy, 2012). Compared to other affluent countries, Canada now ranks at the bottom of UNICEF's ten benchmarks for provision of early childhood education and care (Hill, 2011). On the other hand, in present day Canada, over $75 \%$ of mothers with preschool children are in the paid labor force (Friendly and Hennessy, 2012). This is a sharp increase from $42 \%$ of Canadian mothers in the work force in 1976 (Statistics Canada, 2000). However, this trend has neither led to a significant shift in the gendered construction of childcare nor to comprehensive childcare policies from all levels of the Canadian government (Luxton, 2006).

Today, women in Canada are not only over represented in part-time employment and earn less than men but are also the ones who often give up careers to care for their children. For example, according to Peckford (2009) 40\% of women in Canada, compared to less than $30 \%$ of men, are in part-time, contract, or other non-standard work arrangements. Barker (2009) also explains that even though more mothers have joined the workforce they are still more likely than 
fathers to make work sacrifices for family responsibilities, including taking longer employment leave for childcare purposes, reducing their weekly working hours, voluntarily forfeiting promotion, or seeking a lower-paid job closer to home. Furthermore, Immigrant women are at greater disadvantage compared to Canadian born women and immigrant men. According to a report by the economic council on women, every year immigrant women earn $\$ 2000$ less than Canadian-born women despite the fact that $24 \%$ of immigrant women have higher education as compared to $18 \%$ of Canadian born women (Hill, 2011).

Following the advice of subject Librarians Diane Granfield (Social Work) and Kelly Kimberly (Child and Youth Care), the literature review for this study, started out with searching the library database for the main concepts of the research question. A search for "immigrant mother*” AND ("Child care" OR "day care") AND (Ontario OR Canada*) in Proquest databases, yielded, 1097 results. Upon narrowing the results down by date and filtering for only scholarly materials, 981 results were found. Many of the materials involved either comparative studies or discussions of child care in contexts that were outside the scope of this research. By searching within the results, and searching through other library catalogues, 35 resources, including journal articles, books, e-books and policy reports were reviewed for the literature of on the subject of child care service provision and women's employment. Moreover, the literature for the theoretical frameworks, some of which intersects with the literature on childcare were searched for in a similar fashion. Five scholarly materials on black feminism, two of which are by Canadian academics, were reviewed in order to find links between this study and black feminist theory. Further, five Canadian, one British and two American social reproduction theorist's writings were reviewed. 
The literature reviewed for this research can be categorized in to three inter-related areas; the quality and affordability of available childcare, the debate around public and private childcare services and the relationship between childcare provision and women's equality. The major and recurring discussion in all of the literature reviewed was around the quality and affordability of childcare service currently available in Canada. The state of childcare system in Ontario and in most parts of Canada is plagued by issues like shortage of spaces, uneven quality, long wait lists, varied and unaffordable fees, low-staff wages and weak regulation (Friendly \& Ferns, 2014; Frankowicz, 2007). Full-day kindergarten- now implemented in Ontario has not measured up to the needs of children younger than four and has not successfully patterned with day care providers (Friendly, 2014). Further, appropriate and inclusive options for children with disabilities are still scarce, leaving out many children with special needs (Halfon \& Friendly, 2013).

The federal government's Universal Child Care Benefit of 100 \% dollars a month doesn't begin to address the childcare needs of most Canadian families. Some conservative leaning scholars like (Richards \& Brzozowski, 2006; Baker et al, 2008 and Kottelenberg \& Lehrer, 2013) argue that the UCCB provides choice for families. These scholars often use words like "optimal choices in day care”, "generous subsidies” and "government imposed regime” that invoke the common neoliberal arguments against publically funded social service. However, universal childcare activists point out the rhetoric of choice is only beneficial for upper middle class families who can afford market-based prices (Prentice; 2007, Penn, 2012).

According to the Ontario Coalition for Better Childcare’s latest statistics there are 57,000 licensed spaces in daycare centres and regulated homes in Toronto; just enough spaces for only twenty-one percent of children under ten. Given the fact that up to $75 \%$ of mothers with children 
under ten are in the labour force there is a serious gap between the demand and supply of regulated childcare spaces (Friendly, 2013). With childcare cost as high as 2000 a month in cities like Toronto, most parents' only hope of accessing licenced child care service is to find a subsidized spot (Friendly and Hennessey 2012). Unfortunately there are currently 19,000 children in Toronto's waiting list for a subsided childcare spots and more and more families are joining the list (Friendly, 2014). These subsidized licensed daycare spots only cover $28 \%$ of children from low-income families (Edwards, 2013). The rest of low-income families are left with non-desirable options like using unlicensed childcare or having an adult family member (usually the mothers) stay at home with the children. Lower costs at unregulated childcare service providers attracts many parents to the use of lower cost childcare arrangements that are usually of dubious quality. These arrangements have no public over sight and include unregulated/unlicensed childcare service often offered by relatives, neighbours and other business individuals. According to the Ontario Collation for Better Child Care, six children have died in unregulated childcare in the last few years (OCBCC, 2014).

According to Hoffmann (2010) a survey with 840 parents across Canada shows that there are major inconsistencies in terms of spaces, cost and quality for child care in Canada and that many Canadian parents are dissatisfied with the current state of child care in Canada. The level of public funding for childcare varies widely among provinces. For example, while Quebec covers $80 \%$ of regulated child care costs in that province, the average Canadian province covers only 38\% of costs (Hoffman, 2010).

Another area explored by the research reviewed is the public versus private childcare debate and whether or not childcare services should be universalised. Discussing the rise in using unregulated and private childcare services in Canada, Friendly M, one of the biggest 
supporters of a publicly funded and preferably universalized childcare services in Canada, argues that for most families this is a last resort and many explain that they would prefer a licensed childcare service (Friendly, 2009). According to Timpson and Prentice (2002) research from some of the developed countries that have national childcare programs shows positive impacts of children's developmental as well as women's right's progress.

Given that Quebec is the only province in Canada that has a universalized childcare program, much of the Canadian research on the subject of universalization comes from that province. In Small Town, Big Benefits: The Ripple Effect of \$7/day Child Care, a qualitative research study by Patrizia Albanese (2007), the effects of universal child care on a community located on the Quebec/Ontario border are explored. The findings show that the mothers interviewed were quite satisfied with the program, and not only hoped that it would continue in Quebec, but would also expand to the rest of the country. The study found that, according to the community, affordable childcare was not only a necessity for the mothers to work and study but were also beneficial to the children's learning and emotional wellbeing. The study concludes that the universal childcare program had a ripple effect on the community where the domestic relations improved, jobs were created in the community and the majority of the members of the community were economically better off because of the program (Albanese, 2007). Other researchers like Albanese et al (2010) agree that universalized childcare program is better not just for children and women but for communities overall. Albenese et al (2010) explained that a national childcare program that is of high quality is the cornerstone to producing a future work force that is “competent, innovative, and resourceful” (p.127)

On the other hand using the You Bet I Care! (YBIC) dataset, Doherty, Friendly and Forer (2002) demonstrated that privatization of childcare leads to poorer quality in services. According 
to this research, the poor quality often results from a number of behaviors such as hiring higher proportions of untrained staff, paying poorer wages, generating higher staff turnover and lower morale, as well as program characteristics such as a poorer ratio (Friendly and Forer, 2002). Despite these studies that show how privatization of childcare decreases quality there has been a growing trend of privatization in the last few years in Ontario (Friendly \& Hennessy, 2012). The authors argue that turning child care into a money making venture is regressive and has negative effects on the quality of child care provided. Instead the authors argue for a hundred percent publicly funded childcare system that is widely accessible and is based on comprehensible policies. Further, advocates of publicly funded, non-profit childcare argue that since private companies have an ultimate goal of turning a profit they have an incentive to keep standards low thereby negatively effecting children and families (Penn, 2012).

Other researchers like Baker, Gruber, \& Milligan (2008) who come from a more economically conservative perspective disagree that a universal childcare program is the best option for families in Canada. Baker, Gruber, \& Milligan (2008) argue that the universal childcare program in Quebec has negative impacts on parenting and childhood outcomes. The researchers use ten years of data from National Longitudinal Survey of Children and Youth (NLSCY) to empirically analyze the impact of the policy change on mothers' labor supply, childcare utilization, and child and parent outcomes. The researchers agree with proponents of universal childcare access that maternal labor supply has increased with the introduction of the universal childcare program in Quebec. The researchers, however, question whether this trend is enough to encourage the continuation of the program. For example, the researchers found that, children in childcare programs were worse off by measures ranging from aggression to motor and social skills to illness. The researchers further argue that the new childcare program led to 
more hostile, less consistent parenting, worse parental health, and lower-quality parental relationships. A follow-up study, by researchers Kottelenberg \& Lehrer (2013) also used data from National Longitudinal Study of Children and Youth (NLSCY) together with standardized tests like Peabody Picture Vocabulary test and standardized motor and social development (MSD) to study the same phenomenon. The study found out that the previous study's conclusion that access to subsidize child-care has negative impacts on individual developmental, behavioural, and health measures are strong to the inclusion of data up to ten years after the reform. In a cost-benefit analysis of the universal child care program, both studies questioned the sustainability and the economic sensibility of the program arguing that the monetary allotments used to support this policy appear to be relatively high compared to the advantages from increase in maternal labor supply (Baker et al, 2008; Kottelenberg \& Lehrer, 2013).

Despite the finding from these two studies most researchers and scholars in this field like (Friendly 2009 \& 2014; Prentice, 2007; Friendly \& Hennessy, 2012 and Albanese, 2007) argue that the availability of quality non-parental care leads to higher maternal employment and has been shown to have positive outcomes for children. Similarly, a Canadian study by N omaguchi (2006) shows largely positive effects of maternal employment on pre-school children. Controlling for mediators like longer hours in school settings, fewer positive mother-child interactions, and less reading with parents, maternal employment was related to children's lower hyperactivity, more pro social behaviour, and less anxiety at age four. The results of the study indicated that preschoolers may benefit from maternal employment, but benefits may be offset by long hours of nonparent care and fewer positive mother-child interactions ( $\mathrm{N}$ omaguchi, 2006). 
Finally, much of the research reviewed for this project comes from feminist lens and therefore views access to reliable childcare as central to women's equality. Many years after the 1984 Royal Commission on Equality in Employment, headed by the current Supreme Court Justice Rosalie Abella, argued that; "child care is the ramp that provides equal access to the workforce for mothers.” Canadian women are still struggling to attain economic and employment equality (Childcare Resource and Research Unit, 2012). Almost all the reviewed resources like Skinner, (2009); Friendly (2009 and 2014); Albanese (2007) and Peckford (2009), discussed how the lack of affordable and adequate childcare is a barrier to women's employment and economic independence. For example, in a dynamic analysis of the effect of childcare costs on the work decisions of low-income mothers with infants, Baum (2002) examines the relationship between work hours of low-income mothers of infants and access to childcare. In an empirical research with low-income mothers, Baum (2002) found that childcare costs were a barrier to employment especially for low-income mothers who spent a large percentage of their income on paying for childcare. Similarly, Hill (2011) argues that women with children often have less earning power, as their domestic responsibilities make full-time employment difficult if not impossible. The high cost for childcare in Canada acts as a major deterrent from seeking employment since paying for childcare reduces the net benefit of employment.

In a study comparing maternal poverty in Australia, New Zealand, and Canada (Barker, 2009) found that Canada has the highest poverty rates despite having highest levels of maternal employment. Among other reasons, Barker (2009) attributes the high cost of childcare as one of the reasons why many mothers in Canada are unable to work their way out of poverty. Frankowicz (2007) explains that immigrant women find it more difficult to find childcare despite the fact that it is extremely important for their successful inclusion and settlement in the 
Canadian society. Hill (2011) also points out that while childcare access is difficult for many families, immigrant parents and children might have a more difficult time understanding Canadian unspoken norms, eligibility and subsidy systems in child care programs in their new communities thus making access even harder.

Also, focusing specifically on immigrant mothers, Skinner (2009) argues that access to affordable childcare can be directly related to maternal employment, economic independence and thus autonomy for immigrant mothers. Skinner (2009) points to research findings from Sweden and Quebec that show higher level of immigrant women's participation in the work force when adequate childcare is affordable. Other cross-national studies in Canada like Friendly (2009) and Prentice (2007), have also found that more affordable childcare has positive effects on mothers' employment decisions and economic progress.

Other scholars from this point of view like Harder et al (2004) and Rianne (2007) take on state policies and examine how the state perpetuates women’s economic dependency and subsequent gender inequality. For example, Harder et al (2004) use the Child Care Expense Deduction (CCED) as a site to examine the gendered and patriarchal assumptions that underlay the Canadian policies around childcare and taxation. The author critiques the concept of "equal earning families" where a dual earning family is taxed the same way a sole earner family that earns the same annual income. Harder et al (2004) argue that neoconservative policies like this ignore issues like class location and social reproduction activities like childcare thereby encouraging a patriarchal ideal of a traditional family where women stay at home and care for children. At the same time, Harder et al (2004) point out that while Canadian neoliberal ideologies are not necessarily invested in traditional gender roles and women's non participation in the labor force, they share the neoconservative interest in reducing tax spending and 
government involvement. This view, is also expressed by social reproduction theorists, who critique the state's role in imposing unfair gender roles on women (Benzanson \& Luxton, 2006).

Looking at the link between childcare access debates and politics, a study titled Hiding the Elephant: Child Care Coverage in Four Daily Newspapers by Albanese, Rauhala, Ferns, Johnstone, Lam, \& Atack (2010) did a qualitative analysis of how Canadian media discusses the issue of child care provision. The researchers studied the media coverage of four major national newspapers by looking at trends, patterns, and frequency of childcare discussion over a sevenyear period. The results showed that over the years there was no evidence of a steady or gradual increase in childcare coverage paralleling mothers' increased participation in the work force. However, the researchers observed a spike in media coverage that appeared closely tied to political developments and events suggesting that childcare coverage seem to be a battleground used during elections in order to sway public attitudes. The researchers also noticed that while the coverage of childcare access was lower than expected in all the major papers, of the dailies examined the Toronto Star covered the issue the most frequently while the National Post had the least extensive coverage.

Childcare access and women’s labor force participation are much researched and debated issues in Canada. Despite extensive research and attention paid to these issues there is little information of how the issues affect immigrant women and how they experience childcare access in Canada. Of all the materials reviewed on Skinner (2009), Frankowicz (2007) and Hill (2011), specifically addressed immigrant mothers' access to childcare and employment. Few others, like Friendly and Hennesy (2012), Rianne (2007) and Prentice (2007) referred to immigrant women only when making a point about the further disadvantage of certain groups like low income women, immigrant women and aboriginal women. Noting this limitation in literature, this 
research study aims at filling a small gap in understanding the childcare related experiences of African immigrant mothers. The research looks at the unique experiences, challenges, and limitation as well strengths of African immigrant mothers as a distinct group. Questions like what childcare access means to these mothers and their families, how they feel about their current child arrangements and what they think of the debates pointed out above will be explored in this research. Given that marginalized groups like immigrant and racialized communities are often under-represented in academic research as well as in popular media, this type of research is necessary to bring forth diverse points of view. 


\section{i. Theoretical Frameworks}

The theoretical framework used in this major research paper will be based on black feminist theory and social reproduction theory. These two theories will be used to explore the experiences and narratives of working African immigrant women who use childcare services in Toronto. Both black feminist theory (Collins, 1990 and 2000; Wane and Massaquoi, 2007; Hooks, 1984 and Norwood, 2013) and social reproduction theory (Ungerson, 1983; Bezanson and Luxton, 2006; Armstrong and Armstrong, 1990) have their basis in feminist theory and are particularly concerned with women's experiences and realties. Research based on feminist perspectives is focused on the centrality of gender in shaping human experiences and consciousness (Creswell, 1998). The theoretical frameworks of black feminism and social reproduction theory have been selected with the belief that the right theoretical and conceptual framework is significant in doing social justice research. This is because theoretical frameworks are based on epistemologies, which often determine the direction, goal and outcome of any research project.

Black feminism theory can be defined as "women who theorize the experiences and ideas shared by ordinary black women that provide a unique angle of vision on self, community, and society” (Hill-Collins, 1990 p. 12). Black feminism has originally emerged in response to Black women's alienation from Black Liberation Movement and the Women's Movement. Black feminist like Collins (1990) and Hooks (1984) argued that mainstream feminism solely focused on white middle class women thereby ignoring other groups of women including women of color. This marginalization of Black women's experiences extends to academia and research since few black women have the cultural capital, resources and time necessary for progressing through higher levels of education systems. This marginalization in academia has given white 
middle-class feminists the privilege of gatekeeping positions in terms of feminism and feminist journals (Rina, 2012). These mainstream feminists have focused on a universal sense of sisterhood and have failed to take into account the diversity of needs and realties of non-white women (Rina 2012). Although other feminist of color as well as white feminist have written about black feminism, some scholars maintain that it is a unique perspective that can only come from a dynamic interaction between black women and the multiple systems of oppression against which they have struggled (Saulnier, 2000).

Black feminism also referred to as African-American feminism or Womanism has originated from the United States and has endeavored to bring to the table the struggles, opinions and lived experiences of Black women into academia. Notable and pioneer black feminists include Hill Collins, Bell Hooks, Alice Walker and Barbara Smith. In Canada, notable black feminist include Peggy Bristow, whose collection of essays, We're Rooted Here and They Can't Pull Us Up, covers black women's 400-year presence in Canada. In this book, Bristow (1994) highlights significant histories of black women in Canada, like Canadian women's historiography. It firmly locates Black women in Canada by bringing forth the stories of Black female slaves in Nova Scotia and Black women's role in freeing themselves as well as other enslaved people in North America. While this history is not immediately relevant to this research, which focuses on African-immigrant women, it does reinforce Black feminist stand point about narrating black women's often denied histories and accomplishments. Other Canadian Black feminist works reviewed include Wane (2004) and Wane and Massaquoi (2007). In both Canada and The US, black feminism has a long-standing significant alliance with other third-wave feminist movements like postcolonial feminists, transnational feminism and Africana 
feminism (Saulnier, 1996). Like Black feminism, these movements, have also struggled with being recognized by men in their cultural groups as well white and western feminists.

There are number of reasons why black feminism is a fitting theory in interpreting this research project. Firstly, Black feminism pays great attention to the sociological concept of intersectionality. First coined in 1989 by Kimberlé Crenshaw, the concept refers to "the intersection between gender, race and other categories of difference in individual lives, social practices, institutional arrangements and cultural ideologies and the outcomes of these interactions in terms of power” (Davis, 2008, p. 68). As a theoretical tool, intersectionality demonstrates the lived experiences of Black women and how they are forced to take on multiple oppressions simultaneously on a daily basis (Norwood, 2013). The research subjects for this paper are African-immigrant women who belong to some of the most marginalized groups in our current society. These women's experiences of looking for and accessing childcare service is different from the mainstream mothers' experiences since the later do not deal with similar and simultaneous systems of oppression. Moreover, the use of the concept of intersectionality, black feminism also acknowledges the interlocking nature of these systems of oppression, which explains how different types of oppressions enable and perpetuate each other (Collins, 1990). As opposed to other theories of oppression that view sexism, classism and racism as separate systems of oppression, Black feminist theory uses the construct of intersectional/interlocking oppressions to explain how these systems mutually benefit each other (Collins-Hill, 1990). Black feminism therefore argues for a paradigm shift towards using a model of oppression that understands not only the intersecting nature of oppression but also between the mutual dependencies of different systems of oppression (Collins-Hill, 1990). In this case, immigrant women in Toronto are economically worse off than both Canadian born women and immigrant 
men. For example, a 2011 women’s economic council report found that immigrant women earn about \$2,000 less than Canadian-born women and about \$11,000 less than immigrant men (Hill, 2011). Black feminist theory will therefore be fitting to explore these intersectionalties between race, gender, and economic class. Further, Black feminist theory is unique in that it starts out with the perspective of Black women rather than white men (as many feminist theories do) and centers its analysis on the complex matrix of oppression that black women face (Saulnier, 2000). Another appeal of Black feminist theory for this research is the centrality of motherhood and family in Black feminist discourses. Debates about childcare care provision in Canada are dominated by conservative notions of motherhood or liberal feminist discourses about choice. For example, many conservative politicians, emphasizes the importance of the traditional family unit where mothers assume responsibility for childcare. On the other hand feminist push back for women's empowerment and giving women more choices including the choice of not having and mothering children. What is often missing from this discussion is the centrality of motherhood in many non-western cultures including African traditions. According to Norwood (2013) African feminism is characterized by a noted absence of conflict between reproduction and production since both are viewed as equally important in the totality of human experiences. In many African societies women, with support from extended families, embrace both roles as mothers and economic providers. However in a western, capitalist system, with limited public policy supports, women struggle to combine these roles and sometime have to choose between them. These debates between liberal feminists and neo-conservative groups also echo an assumption that the choice between the two roles is possible and easy to make. However, this is not true for many overlapping groups of marginalized women including women of color and women living in poverty. Hill (1990) explains how African American women have long worked outside the 
home and how their paid labor in the market -place as well as their unpaid labor in their family households did not fit within predominant understanding of work and family as separate spheres. In present day Canada, certain realties including the overrepresentation of Black men in the justice system and the separation of families through immigration, make it even more necessary for black women to participate in the labor force.

Finally, while black feminist theory was originally developed to interpret the experiences of African American women in the US it has later been expanded to Black women in Africa and in the rest of the diaspora, including Canada. In addition to being a response to White feminist's neglect of Black women's issues, Black feminism in Canada has also emerged of Black people's struggle for visibility in Canada. Despite the fact that Africans have been in Canada as long as Europeans and are among the nation's founding peoples, their contributions are often marginalized in Canadian national discourses (Wane, 2004). This erosion of black people from Canadian history, helps maintain the image of Canada as a "White settler’s society” (Wane, 2004). Furthermore, much of the Black feminist perspectives in Canada are based on diaspora experiences of immigration since most Black people living in a Canada are descendants of immigrant from Africa and the Caribbean (Wane and Massaquoi, 2007). Canadian Black feminism will therefore shed light as to how immigration factors into the lives of Black women in Canada. Additionally, some Black feminists like Norwood (2013) argue that despite geographical differences, Black women in Africa, North America and the Caribbean share common struggles arising from shared (albeit varied) experience of colonial subjugation. Colonial subjugation refers to oppressive actions of colonial and imperial systems. The shared experiences of colonial subjugation include some unifying experiences of Black women like 
struggles for self-definition and visibility, as well as struggles against patriarchy and economic oppression.

Social reproduction theory, as discussed by, Ungerson (1983), Bezanson and Luxton, (2006) and Armstrong and Armstrong (1986 and 2004) is also another feminist theory that will be used to interpret this study and its findings. Social reproduction is a theory from feminist political economy and refers to "the activities and attitude, behaviors and emotions, responsibilities and relationships directly involved in the maintenance of life on a daily basis and intergenerationally.” (Luxton, 2006 p. 35). Among other things, social reproduction includes making food and clothing available for daily consumption, caring for children and seniors as well as the social organization of sexuality (Bezanson and Luxton, 2006). In talking about social reproduction, feminist political economy has been successful in making visible and problematizing what would otherwise have been invisible or seemingly trivial to society including liberal feminists (Sedef, 2006). This was done by shedding light on how the mental, manual and emotional labor of women provides the social and biological care necessary in the day-to-day life as well as in reproducing the next generation (Luxton, 2006).

Feminist political economy approaches the issue of social reproduction from a familymarket nexus by stressing interrelatedness of state and market actions and gender inequality present in society. An example of this interrelatedness is the tension (and sometimes) incompatibility between women’s economic independence and their traditional roles as providers of care including childcare (Frankowics, 2007). The theory, explains how state decision at the national level are influenced by patriarchal gender norms that hinder women’s economic independence. States "promote through a range of policies, an ideal family life in which women care for and nurture others” (Ungerson 1998, 3). These policies are based on the essentialist 
notion that women are natural caregivers and should assume responsibility for social reproduction roles (Frankowics, 2007). Neo-conservative policies, informed by patriarchy unfairly reward traditional male-earner female-caregiver families (Harder et al, 2004). An example of this is the tax deduction policies based on the idea of "equal earning families" where dual earning families are taxed the same way as sole earner families of the same annual income. These policies ignore issues like class location and social reproduction activities like childcare thereby unfairly punishing families who either choose not to or cannot belong to what is considered the ideal Canadian family (Harder et al, 2004). Further, austerity measures and continuous cut backs on social programs are other ways in which both neo conservative and neoliberal policies hinder women's economic independence. Social reproduction challenges and raises questions about the role of women's domestic and economic labor in capitalist societies like ours (Frankowics, 2007).

Moreover the domestic labor of women, some feminist theorists have integrated class oppression and the cultural devaluing of waged care work often performed by poor women. These theorists take on the state's role in mediating between and regulating the relationship between families and markets. By taking up this analysis, social reproduction is able to observe how national and even global policies related to social reproduction oppress women (Luxton, 2006). For example, issues around transnational motherhood and the patterns of immigrant lowincome women providing cheap labor for social reproduction are explored in the theory (Sedef, 2006). The extension of social reproduction theory to international contexts has further implication for immigrant women, such as the ones participating in this research, who might be involved in poorly paid waged work that involves providing care. 
The above background discussion of the theories used in the research illustrates how the theoretical framework selected fits with this research project. Black feminist theory is invaluable in examining the experiences and narratives of Black women in North America. The theory’s recognition of the extent to which gender, race, class, sexuality, and citizenry intersect will be used as a lens to understand the social and economic marginalization of African women in Canada. Since much of the current Black feminist theory is based on American perspectives, social reproduction theory (which used more extensively in Canada) will shed light on the relationship between women's economic marginalization and state policies in Canada. Together these two theories are expected to give great insights in interpreting findings from this research and proposing recommendation 


\section{Methodology}

\section{Research Goals}

This research is aimed at exploring working African-immigrant mothers' experiences related to accessing childcare service in Canada. The aim of this exploratory qualitative study is to understand the lived experiences of African immigrant women and their narratives in relation to childcare services access in Toronto. The research question asks "How do working Africanimmigrant mothers experience the use of formal childcare service in Toronto?” Given the fragmented and scarce nature of childcare services in Toronto, the study is interested in interested in learning more about these women's experiences in looking for and accessing licenced childcare service. The study is also interested in learning about what challenges these women face while they access these service and what strengths allow them to work and mother at the same time.

\section{Data Collection}

The research participants for this project are African-immigrant mothers who live and work in Toronto and have had the experience using formal child care services. The mothers in this research have children ranging from ages three and half to ten years old and have all used licenced childcare service for their children at some point while they worked. While there are many people from all over the world who self-identify as African this study only focused on mothers who have emigrated from the continent of Africa. For this reason all of the women interviewed were immigrants from the continent of African and have emigrated from Eretria, Nigeria, Somalia and Kenya. Moreover, since the experience of immigration is believed to make a lot of difference in how these narratives are constructed, the research only recruited mothers 
who have emigrated from Africa as opposed to second or third generation African mothers who were born in Canada or mothers who have immigrated from other Diasporas. The study also focused on mothers who use or have used childcare services in Toronto while they work and excluded mothers who have used these services while they were involved in other activities such as going to school or volunteering. This is because the researcher is particularly interested in the combination of work and motherhood and how this affects women's experiences and opinions about childcare access.

The research recruited mothers who are currently using formal childcare services or who have used it in the past. This is because this group of mothers are in the best position to discuss both the experience of searching for childcare services as well the quality, affordability and flexibility of the childcare services they use in the present or have used in the past. While there are several childcare arrangements available in Toronto, the scope of this study is only limited to the use of licenced, formal childcare service. These formal/licenced childcare services explored here include both home-based or day care centre based. Three of the mothers in this research are still using formal childcare services while one has stopped doing so and is now staying home with her son. The women have all used subsidized formal childcare services while they worked full time. Three of the four women have also previously used unregulated childcare services even though this study only focuses on their experiences of formal childcare service.

Three of the four participants interviewed were married and in relationships while one is a single mother. All the women in the study spoke English as three of them have received formal education In Canada and two of these three women have a university degree. The fourth participant has had some university education in Kenya before she immigrated to Canada. Only one of the participants in the interviews communicated that she is happy with her field of work 
while the other three mothers had to put their dreams of further education and search for better jobs on hold while they worked and cared for their families. The women's current and recent work history includes working as a bank teller, cashier, personal support worker and store cleaner. While information on the women's income was outside the scope of this research, it was observed that all the mothers are renting apartments and that they are all working class mothers whose jobs are a major if not the sole source of income in the families.

The four women interviewed for this study were all recruited through informal community groups and spaces. Even though this study considered using settlement agencies and formal community centre to recruit for this research it appeared more favourable to use informal recruitment methods to find participants. This decision was influenced by the limited time frame available for the MRP and the fact that formal agencies require time to review and approve project proposals before allowing researchers to recruit from their programs. A non-random purposive snow sampling method was used to recruit participants for this research. This has involved taking flyers to community spaces like apartment building with many African populations and to a few community meetings. Following the snow balling sampling method, the study also asked recruited mothers if they know anyone else who fulfils the criteria and if they could pass flayer along to the communities. This method of recruitment is often used in qualitative studies that target specific population and involve hard to reach populations (Van de Sande, 2011). However, the snowballing effort did not work as expected and none of the participants recruited knew each other or helped the researcher find more mothers.

Once potential participants expressed interest in participating in the research a quick screening process was done over the phone and email in one case where, the process was aimed at determining eligibility for the study and one mother was eliminated as she was not working at 
the time she accessed childcare services. After this was determined, a mutually convenient time and place was selected for the interview. Some of the interview locations suggested included private Toronto public library rooms as well as private study rooms at the Ryerson University library. Informed by researcher’s previous experience of doing research with African and Caribbean women (most of whom preferred doing interviews at their homes), participant’s homes were also included as a possible location for interviews. This was done in part as a commitment to accommodating participants' time and preferences. Further, in accordance with the researchers familiarity with African cultures where inviting people over to your house is a sign of respect and trust, the researcher did not want to turn down such an invitation and thereby risk losing trust or offending participants. Consequently, three of the four mothers interviewed asked for a meeting at home and the only other interview was conducted at a Ryerson University study room.

To collect data for this study one face-to-face, in-depth interview was conducted with each participant. The interview used a semi-structured interview guide and participants were given a chance to look over the guide and ask any question before the interview started. The flexibility of the semi-structured guide compliments the study, which is qualitative and exploratory in nature. It is also compatible with narrative data collection methods where interviews usually follow a conversational style with the participant guiding the conversation. Chase (2003) recommends that apart from their first major opening question researchers should ask questions that follow from close listening to the narrator's story rather than ask questions from their interview guide and this style was used to some extent.

In order to ensure the highest possible level of accuracy, the researcher asked to audiotape the interviews and transcribe them later. However, since some participants might not 
agree to have their interviews audio taped, an option was provided for participants who wish to participate without their interview being audio recorded. Two of the four participants opted out of the interview recording while two others agreed to have the interviews audio-taped. In the case of the latter two interviews the researcher has taken extensive interview notes from the interview. All participants were given the option to review the interview transcript either over phone, email or by having another face-to-face meeting. However, only one participant asked if she could look over the notes taken by the researchers and wished to remove a few facts she disclosed during the interview. Further, the researcher also kept field notes and personal journal entries during the course of data collection and later during data analysis. The notes were used to capture phone conversations before the meeting, feelings and other experiences from data collection and data analysis. Having participants review the transcripts and using field notes as well as journal entries was part of the researcher's effort to triangulate the research and ensure a high a level of reliability.

This study has used narrative inquiry research methods for both data collection and data analysis. Narrative inquiry is defined as "an interdisciplinary study of the activities involved in generating and analyzing stories of life experiences (e.g., life histories, narrative interviews, journals, diaries, memoirs, autobiographies, biographies) and reporting that kind of research. (Schwandt, 2007, p. 204). Similar to what the researcher has tried to do in this study, narrative inquiry studies life experiences and places emphasis on how people live and think about different aspect of their lives. This emphasis on narration and personal meanings was important for this study, as it has allowed for the participants to frame their own life experiences and assign meanings to them. 
Narrative methods of inquiry are also unique in that they reveal our own investment in the research with participants along the way (Frasier, 2004). This aspect of narrative inquiry is important to this study in creating a point of connection with the participants. Narrative inquires also allow a room for stories or comments that do not appear to be immediately relevant in the study (Chase, 2003; Frasier, 2004). For example, while narrating their experiences about childcare participants told stories about their own educational past and aspirations that did not seem immediately relevant to the research but were found valuable while doing the data analysis as they pointed to what women have to sacrifice to care for their children and families. Another appeal related to the use of narrative inquiry for this study is that story telling (as is done in narrative inquiry) is a significant part of Afrocentric traditions. Since the participants of this study are African women like the researcher, it was hoped that this method of data collection was more organic and natural to them as opposed to using surveys or structured interview questions.

Finally, since narratives are powerful tools to reinforce but also contest dominant social practices, this study has paid deliberate attention to the link between the personal and political in the data collected. According to Frasier (2004) a narrative analysis offers us a way to understand the role that personal stories play in the making of socio-political worlds because narratives understand that the social world is embedded in an individual's stories. This understanding is very compatible with principles of anti-oppressive social work in general and black feminist theory in particular, which largely inform this study and the researcher's view on issues like race and gender

Self-reflection was very important for this study and was exercised throughout data collection and analysis for this study. As previously discussed in the introduction section, there are both similarities and differences between the researcher and the participants in this study. 
The researcher is an African woman who shares certain cultural values with the participants and spoke some of the African languages that the participants spoke like Somali and Swahili. However, there were many differences including the fact that the researcher has no children and that she has completed high reduction in Canada, which has afforded her better job opportunities in the past. While recruiting the participants the researcher made an effort to make it clear that she had not just an academic interest but also a personal investment in the topic as well. The researcher also explained that while she has read much about balancing work and child-care responsibilities she hasn't had the lived experiences such as the mothers in the study. Finally, the researcher was upfront about some of her past struggles with job search and her experiences working in minimum wage jobs like cleaning ad cashiering. All of these disclosures were made upfront during the recruitment conversation or before the interviews started so the researcher could show her sincere interest in these mothers' stories all the while creating a relationship founded in shared experiences, empathy and honesty.

The researcher also notes in her private journal that she struggled with what appeared as the participants"' complicity in the patriarchal norms in their households. The researcher had to make an effort not to stand in judgment as to why the women in the research would accept responsibility for most, if not all, of the household chores and child care responsibilities while working just like their male partners. Self-reflection during data analysis was important in separating the researcher's opinion from the data. 


\section{Findings}

The four women interviewed for this study have all used formal childcare services while working. The main themes that emerge from the interviews with the participants include dissatisfaction with the state of childcare services used, patriarchal gender roles in the participants' households and lack of extended family supports due to immigration. Despite these emerging themes of struggle and challenges I have also observed a number of positive trends emerging from the interviews with the women. These include a sense of pride in managing hectic schedules and a hope that with their sacrifices their children can have better future in Canada. The women interviewed for this study have all managed to work fulltime while taking sole or most of the responsibility for caring and household tasks. In this section, I will discuss the three main findings of this research regarding the experiences of working African-immigrant mothers who use formal childcare in Toronto.

Before presenting the main findings of this study, I have decided to write and share personal narratives about the four women interviewed for this study. These personal narratives use pseudonyms and were constructed after the interviews with the participants were completed. The narrative were written and are presented here in order to give the reader a window into some of the aspects of the participants' lives especially as they relate to the topics discussed. The personal narratives were constructed using the information from the interview and describe major aspects of the participants lives such as; their families, their educational background, their work and their child care use. Later, the interviews, the field notes and these personal narratives were used to draw out major themes from the experiences of the participants. These themes were examined and discussed in detail in the analysis section. 


\section{Fiyori}

Fiyori came to Canada through family sponsorship fifteen years ago. Fiyori had a primary school education when she arrived in Canada and continued on to high school after coming to Canada. Soon after finishing high school Fiyori started thinking about going to college or university to study nursing. However, Fiyori's family in Eretria told her often they were anxious for her to start working and financially support them. While Fiyori worked full time and put her dreams on hold, she met her partner and her firstborn daughter was born soon after. Fiyori took maternity leave and went back to her full time cashier job after her daughter was 8 months old. Two years later Fiyori's second daughter was born and she took another leave to nurse her new born. After the two daughters were one and three years old, Fiyori applied for a subsidized daycare and got spots for her daughters. At that point Fiyori had to care for her daughters and her family back home who were depending on her, so she realized that she could not go back to nursing school. However, she was determined to work in the healthcare field and started saving up for a personal support worker program. In order to save for the courses Fiyori took on extra shifts at work and started a six month PSW program. Fiyori now works as a PSW for seniors living in their homes. She says she wishes she could go on to nursing school but she is content with her job and feels like the sacrifice she made for her mother in Eretria and daughters makes everything worthwhile. 


\section{Angela}

Angela’s family immigrated to Canada from Nigeria a few of decades ago. Angela was just a baby when her family came here but she went back to Nigeria and came back when she was in her twenties. Angela is the mother of two boys; one neurotypical and one autistic. Angela works fulltime as a bank teller and says she enjoys her job a great deal. Angela uses formal childcare services for her two sons but her older son with special needs could not be accommodated at the same daycare centre as her younger son. Angela therefore uses a home-based licenced care for older son and a daycare centre-based care for her younger son. She feels like going to daycare has been good for both her son's social skills and has helped them interact with kids from different backgrounds. However, Angela is a single mother and has to do everything by herself which leaves her no time for breaks or to do something for herself. Angela wishes that her two boys could go to the same daycare centre so that he older son could have all the extra benefits of being at the centre. She also wishes that her job was a little more flexible and accommodating so that she could spend a little more time with her children especially with her autistic son whose home-based daycare is not very reliable.

"I think (as an immigrant woman) you have to fight more for your job; that is just my personal opinion. You have to kind of do that, you have to make sure no external forces impact you. With my kids I make sure that, because I need to fight harder everything else has to be taken care of." 


\section{Zeynab}

Zeynab is a Somali-Canadian mother who came to Canada eight years ago. Before coming to Canada Zeynab has lived in Kenya as a refugee for one and half decades and is therefore familiar with the experience of immigrating. Zeynab is the mother of a four year old boy and was expecting her second baby during the time of this research. Zeynab is no longer using child care service but has previously used it for a year while she worked full time. During this time Zeynab was working as a cashier one time and a group home support worker another time. Two years ago Zeynab quit her job to stay at home with her son because she did not like the subsidized childcare services centre that he attended and could not afford to pay for childcare service in the community that she liked better. She also did not feel like her net income after child care, transportation and her time was worth the time away from her son and the less than perfect care he was receiving. Zeynab, who has a sociology and psychology degree from the University of Toronto would like to go back to work but is not optimistic about the possibility of getting a job in her field or a childcare service that is both affordable and of good quality.

"First of all, having access to childcare service and being able to work is great. However, it is difficult when you have to work odd hours or irregular shift or even, sometimes to have to stay behind and work extra hours. This is difficult because daycares usually close around 6pm and you always have to choose between finishing work or leaving work early to pick up your child from daycare." 


\section{Lisa}

Lisa, a mother of three, was sponsored 5 years ago by her husband who is a Canadian citizen. She was already a mother of two when she came to Canada and has had one more child since her arrival. Lisa's children; two girls and a boy are aged three to nine. Lisa has faced significant barriers finding work and childcare for her children but after a year-long job search and more than a year on the city's subsidy wait list she was able to start work as a cashier and find licenced childcare for her children. Currently Lisa's three kids are in two separate daycare centres in her neighbourhood where she also has a cashiering job at a department store. Lisa was in the middle a business degree when she left Kenya but has not succeeded in going back to school in Canada. She found out that since none of her school credits can be transferred she would have to start over and is not sure if her family can afford the time and money required for starting university all over. Lisa has just started feeling settled this year and is worried that altering her routine will plunge her back in to the difficult struggle of the first five years. She continues to work and wait for her citizenship while her kids go to school.

"As an immigrant black woman it is a little hard to find a stable 9-5 job. It is even harder when you don't have post-secondary education..." 


\section{i. Challenges from state of the childcare system in Toronto}

While all the participants interviewed for the research have been lucky to find subsidized, regulated child care spaces for their children, they have all had to use unregulated care at some point and have all been effected by challenges due to the state of childcare service in Toronto. For example, all the participants have had to go on a waiting list for a subsidized spot for different lengths of time. Explaining the long waitlist and complexity Zeynab said;

"Then, you will have to wait for months and months on a waiting list for the subsidy money. Sometime, when you get approved for subsidy, all the daycare in your ward are either full or not accepting subsidy. If I had the money, I would be able to take my child to any daycare I want."

While Fiyori who has applied for childcare subsidy 8 years ago had a shorter time of 5 months on the waitlist, Lisa had to be on a waitlist for over two years for subsidized spots for her children. According to Lisa, she has missed on the opportunity to look for economic and educational opportunities in the crucial first couple of years recently immigrated mother because she had to stay home with her children. Having just started working last year after securing subsidized childcare services for her children Lisa explained that she felt like this is the first year that she has felt settled in.

Another issue that all of the mothers in the study continue to struggle with is the lack of flexibility in the formal childcare arrangements. For example, Fiyori and Angela both talked about the extra charge of $10 \$$ a minute for parents who are late to pick up their children from daycare. Angela, who has to drive to and from a daycare centre for her younger son and a homebased licenced care for her older son, described;

"The biggest thing is that I have no time for myself at all. I leave home and 6, I have to drop them at 7, and then in the evening I am driving like maniac to pick them at 6 and even after 6 you get charged." 
Zeynab and Angela both explained that their precarious employment work schedule and everyday life sometimes makes it difficult to be there on time every day. Fiyori who works close to her home had to be late a few times but is feels lucky that during those times her sister was able to pick up the children.

Two of the four mothers interviewed, Fiyori and Angela, also brought up the issue of rules and regulations around their children not being accommodated in the daycare centres of their preference. Fiyori who is a mother of 8 and 10 year old daughters was recently told that her 10 year old will no longer be able to attend the same day care due to age regulation. Fiyori told me that she is really anxious about moving her daughter to a different day care since it will increase her work, separate the sisters and force her daughter to adapt to a brand new environment. Fiyori who did not know about this rule until recently was hoping that her daughters could stay at the same centre until the oldest was 12 and they could watch each other.

Even more inconveniently, Angela has always had to use two different care services for her boys. Angela's oldest son is autistic and would not be accepted in to the mainstream day care centre that her younger son goes to. Angela therefore had to use a home-based licenced caregiver who has special training in the care of autistic children. Angela who works full time does not like the fact that she has to drive to three locations twice a day and wishes that one daycare in her neighbourhood could take care of both her children. Angela explains;

"... oh yeah I have been trying to get him in to regular day care. If I had a choice they will be in the same day care...he would be in regular day care."

Even more importantly, Angela doesn't like that her son do not get to spend enough time together. 
“....yeah because they don't to get to see each other throughout the day. The only time they see each other is at $6 \mathrm{pm}$ and then you are getting them ready to go to be. And also for you transporting them it also makes them easier instead of two locations."

Angela also feels that different children like her two boys could learn a lot from each other and believes that all regulated daycare centres accommodate children like her older son. Angela explains;

"I think my son can learn a lot from kids who are different and they can also learn from him. Like my two sons play and do things together."

Lisa and Zeynab both had other major issues with the quality of the care their children were provided. In fact the poor quality of the service has forced Zeynab to quit her job and stay at home with her son for the last two years;

"I didn't like the childcare service I used. But I had to use anyways. One of the things I didn't like is that most of the teacher at the daycare are not educated and barely spoke English so it was hard to understand sometimes. The other thing is hygiene. My son would get sick almost every week (flu, pink eye, rashes etc.) then I would have to call my work and let them know that I can't come to work until my child is ok to go back to daycare.

Zeynab hopes to use informal networks care arrangement when she goes back to work in a year since she feels like she might not able to get back to the subsidized childcare spots.

Describing her dilemma, Zeynab explains;

"That is why I am thinking about using someone I know who takes care of kids for cash if I go back to work. I don't think it will be easy to get subsidized daycare that is good for my kids."

Another finding is that the service received might depend on the neighbourhood you live in. According, to Zeynab, access to subsidized services depends on the neighbourhood you live in since you have to use daycare centres in close proximity to your postal code. Zeynab explained;

"As I said before, as an immigrant woman living in predominantly immigrant, poor neighborhood, my experience with accessing childcare is different, say, compared to white or non-immigrant women. 
This is because Zeynab says;

"I think what makes my experience as an African woman different is my income level and the neighborhood that I live in. If you are low income, you are more likely to live in subsidized housing which means you will live in poor neighborhood. This also means you can't just apply any daycare center in Toronto. You will have to apply within your ward/neighborhood."

Zeynab felt like the staff at her former daycare centre were not well trained and that the children often got sick due to high number of children in the same centre;

"The other thing is hygiene. My son would get sick almost every week (flu, pink eye, rashes etc.)... I think my former daycare was also crowded...so the kids were always getting sick.”

She also found that her "...son was not eating at daycare. Everyday his food came back like it was."

This last complaint is in contrast with Fiyori experience of feeling that the workers treated the children very well and always ensured that they had eaten. Fiyori even remembers a particular incident when the day care workers called in a nutritionist for a two-week period to work with her younger daughter who has a generally poor appetite.

Two of the mothers interviewed felt like attending non-parental care is actually beneficial for their children. Fiyori, feels that the daycare workers values and disciplined methods have complimented hers well and that her kids are better behaved because of attending the day care. Angela also explains;

You know me I try not to judge anyone but personally I feel like my kids in day care is an advantage. For example, some kids I see in day care when their parents bring them and because the kids have been home for so long they don't know how to interact with other kids. For me I find that the kids that have been home they don't know sharing of the toys and being able to sleep on their own without their parents and even food learning about different culture.

Owing to the lack of a national childcare program we see that the childcare system in Toronto, just like in much of Canada is, is inadequate, inconsistent, and vulnerable to political 
change. As we can see in the examples and findings above these issues with the childcare system have a daily impact on the lives of the participants and their families who due to their social and class location cannot afford to use childcare arrangement of their own preference.

\section{ii. Child Care-Women's Work}

Three of the four women interviewed for this study are living with a husband or a partner while one of them is a single mother. From the interviews with the women, it is clear that there is strong patriarchal gender dynamic in the women's households. Only one of the four women interviewed, Zeynab, got help from her husband in applying for child care service while the three other participants had to solely deal with the whole process on their own. Zeynab, a mother of one, explained;

"My husband put in the initial application for daycare but I was the one who would contact daycare centre to see if they have spaces available or call children's service office to see how far along we are in the waiting list for subsidy. When my son was in daycare I always contacted them and dropped off and pick him up."

Zeynab further explained "My husband used to drop us off sometime on our way to work but in terms of getting the baby ready I have to do it." Describing her other responsibilities Zeynab says;

"It is definitely easier now because when he was going to daycare I had to make his food and snacks the night before and pack everything in the morning while I get him and myself ready."

All three participants currently in partnerships/marriages explained that their partners work

long and irregular hours. Zeynab’s husband works at his own business and often works about 14 hours a day. Fiyori's partner also drives a taxi and often works late into the night. However, both Zeynab and Fiyori told me that even while working as many or close to as many hours as their partners they still took almost all responsibility for the care work in the family including childcare. 
From the interviews, direct observation and talking to the women the list of activities that the women do includes applying for childcare care, calling around to find daycare spots, dropping off and picking up the kids from care as well as other household work like cooking and packing food for the whole family, doing laundry, cleaning and grocery shopping. In addition to this list of activities, Fiyori explained that she often takes her kids to extra school activities like homework clubs, libraries, swimming and games. Fiyori explained that she does all of these to “keep them busy”.

Angela who is a single mother explained that, it is just as tough on the weekends when daycare is closed and she has to catch up with everything. Angela explained;

"And when you are not working you are with the kids. On weekends I have to try and catch up with everything. Imagine I have to take them with me to do shopping and do my hair sometimes."

Lisa and Fiyori ,who live with their partners, told me that they are the primary full time caregivers of their children and that their partners only care for the children on few occasion when the women are not home. As a result of working both inside and outside the home the mothers in this research have little to no individual time left for themselves. Fiyori, the first participant interviewed explained that the only friends she has and is able to see are mothers like her who she interacts with while the kids play, go to the homework club or watch a movie with other kids. Fiyori further explained that she hardly leaves home to do personal things and works around her daughter social schedule on weekend and off days. When I asked Angela if she gets anytime to do personal life she explained;

"I leave home and 6, I have to drop them at 7, and then in the evening I am driving like maniac to pick them at 6 and even after 6 you get charged... so you don't really, there is no myself and I time. And when you are not working you are with the kids." 
Apart from being exhausted from their many responsibilities another issue that surfaced in three of the interviewed I did was the women having to postpone or put off individual dreams for a better job or higher education. Fiyori told me that she has always wanted to get a nursing degree but could not afford to take that much time of work so she decided to settle for a six month personal support worker certificate instead.

Lisa on the other hand has left university in the middle when she joined her husband in Canada and has since been unable to go back to school. Lisa was almost done with a business degree but was told that none of her credits could be transferred and would therefore have to start over school. When Lisa and her husband realized how much it would cost to go back to school she knew that she had to put that off and focus on a job search so she could contribute a muchneeded income to her family. This financial constraint, coupled with the lack of childcare services she faced in the first year and half, have also delayed the possibility of finishing higher education and getting "better" employment.

On the other hand Zeynab was lucky enough to complete her degree in sociology and psychology after she had her son in her last year of school. However, Zeynab told me that she is currently unemployed and staying at home with her four-year-old son. Zeynab has worked as a cashier and group home worker during and after her degree but when she became dissatisfied with her son's daycare she decided to quit and stay at home. She explains

"I have my degree in psychology and sociology from $U$ of $T$ so if I had a job in my field and got paid a salary, it would be better. But I was working for a little more than minimum wage and that is why it was too much."

Zeynab who is just having a second baby hopes to get back to the job market but is very pessimistic about the possibility of finding employment in her field and affordable quality childcare services. Zeynab says; 
"First of all, having access to childcare service and being able to work is great. However, it is difficult when you have to work odd hours or irregular shift or even, sometimes to have to stay behind and work extra hours."

Describing the dilemma between staying at home and using sub-standard childcare

services Zeynab further says;

"That is why I am thinking about using someone I know who takes care of kids for cash if I go back to work. I don't think it will be easy to get subsidized daycare that is good for my kids."

Speaking on the choice between staying at home Angela, a single mother of two thinks that being in the labour force and working is better for her and her two sons. Angela explains;

"Also it is better if your kids see you working. All of us in my family work because my mum always worked. It was never an option. She has a degree in something, telecommunications and was always in that field. Growing up in Nigeria and most of us kids worked. Some of my friends their parents never worked and to them they are open to staying at home. Me I am not. I can't stay home.

However, Angela acknowledges that the cost is prohibitive for some families and some people might choose to stay at home with their kids;

"...Sometimes depending on the number of kids you have it might be better staying home depending on the amount of money it will cost you but for me depending on their developmental stage, I prefer my kids to be out there and mingle with other kids."

\section{iii. Immigration and loss of Extended Family Support}

Extended family supports are not only more invaluable in African cultures but are considered a vital part of successful settlement for many new immigrants to Canada. All the mothers in this study grew up in families and environment where the extended families helped care for children and lived with or close to the families. Zeynab explains

"When I was growing up my mother worked and I was watched by my aunts and grandmother. All the kids would play outside with each other and one of my aunts will call us all when it was time to eat. The bigger kids also watched us" 
However, due to the change in the environment from their home country to Canada extended family support is either all together unavailable or impossible to get. While Fiyori and Angela both have some extended family in Toronto Lisa and Zeynab have no family or in-laws in the greater Toronto area. However, all of the mothers told me that they rarely get any support for childcare. The participants explained that tough work scheduled make it impossible to see other family members regularly let along getting support. Angela explains;

"It is good to have family around sometimes but actually I don't get much help because they all work so I don't really get a lot of help... I know that if they were free they would help."

While three of the four interviewed mothers currently have access to childcare services they explained that there are still times when they get stuck and need help. For example, Angela, a single mother, explained

"On weekends I have to try and catch up with everything. Imagine I have to take them with me to do shopping and do my hair sometimes."

Additionally, Angela's older son who has autism goes to a home-based licenced care which is not always reliable. When I asked Angela if childcare responsibilities affect her work she responded

"Yeah that is another problem with home based childcare; like this other day she just said she has a family emergency. I had to call off work and stay home. But when you are at regular daycare there is always someone in the office and if someone calls in they always have back up. But because of the home based care I always have to stay home and use all my vacation days."

Angela further explained that this unreliability is one of the main reasons why she wishes she could get her son into "regular" day care where there is always back up staff.

Another way in which immigration effects the experiences of the mothers has to do with the complexity and difficult of sponsoring family members from abroad. Lisa who has no family 
or in-laws in Canada explained how together with her husband she tried to sponsor her mother to join them in Canada. Lisa was hoping that with her mother here to watch the children, she could manage to go back to school and work at the same time so that she can find a job in her field of interest; business. However, after inquiring and submitting information on their income Lisa found out that this was impossible and they decided to apply for a temporary visa program where citizens and permanent residents can sponsor their parents to stay in Canada for up to five years. While everything else about the program seemed manageable and Lisa was getting excited about the possibility, they found out that would have to take a medical insurance plan for her mother and that the cost of this insurance was out of question for them.

This challenge is not explored in the literature that I have reviewed that talks about women's ability to mother and work. However, all four participants in the study brought up the point about limited extended family supports. Coupled with the gaps in the childcare system and the patriarchal gender norms, the lack of extended family makes the experiences of these mothers unique and more challenging than most. In the next chapter, I provide an analysis of the how issues around these findings; state childcare policies, patriarchal social reproduction norms and the participants' immigrant history affected these women’s experiences and what this implies for social work practice and research. 


\section{Analysis}

\section{i. Challenges from the state of the childcare system in Toronto}

The fact that conventional childcare arrangements do not work for more marginalized families is documented in the research on childcare quality and access. A major issue that rises from the findings is that issues around long waitlist, poor quality and lack of flexibility in the childcare services available.

For example, Prentice (2007) explains that space for extended hours or evening care is not often available for families who need them since most facilities provide care during regular business hours of Monday to Friday. This rigidity in the system can be especially troubling for poor, immigrant and racialized women who are over represented in precarious and shift work employment.

All of these issues with costs and lack of subsidized spaces attract many to the use of lower cost childcare arrangements that are usually of dubious quality. These arrangements have no public over sight and include unregulated/unlicensed childcare service often offered by relatives, neighbours and other business individuals. According to the Ontario Collation for Better Child Care, six children have died in unregulated childcare in the last few years (OCBCC, 2014).

While the mothers interviewed for the research all struggled with certain aspects of the state of childcare like the waitlists and rigidity of rules there were variation in some of the experiences. For example, Zeynab felt that her subsidized care was of inferior quality, the staff members were poorly trained and her son wasn't probably fed. However, Fiyori, who has been accessing a subsidized childcare service for 8 years, says that the staff members are very professional and go above and beyond to take care of the children. 
Despite the variation in experiences the literature on quality of childcare services shows that poor families have less access and are over represented in low-quality childcare arrangements (Prentice, 2007; Friendly \& Hennessey, 2012). According to Prentice, this pattern holds across provinces including the much-admired province of Quebec. A study in Quebec showed that one in five centers attended by children from less privileged families was of inadequate quality, in contrast to less than one in 10 for children of better-off families (Japel, Tremblay, and Cote, 2005). According to this study low income families "have the most to gain from high-quality care yet are the most likely to receive low-quality services'” (Japel, Tremblay, and Cote 2005, 6). With a close examination of childcare states across three Canadian provinces, Prentice (2007) concludes that, poor children have less access to child care compared to affluent children and the child care they access tends to be of lower quality. The findings from prentice (2007) research and (Japel, Tremblay, and Cote, 2005) are similar to Zeynab’s assertion about poor services at poor neighbourhoods that also have higher number of immigrant families. Expressing a sentiment Zeynab says;

"If you are low income, you are more likely to live in subsidized housing which means you will live in poor neighborhood. This also means you can't just apply any daycare center in Toronto. You will have to apply within your ward/neighborhood.”

Another issues that raises from the findings is the lack of proper inclusion for children with special needs. For example, when I asked Angela if there are particular incidents or memories that stand out from her experiences she responded;

“...not at the day care but looking for daycare for my autistic son was a shock to me. You find that even though we, everyone is treated "equally" I was rejected many times because of that autism because they keep saying we cannot do it."

This lack of proper inclusion for children with special needs has been criticised by many childcare advocates (Halfon \& Friendly, 2013; Prentice, 2007). Halfon and Friendly (2013) 
argue that including children with disabilities in regulated childcare systems is a human rights issue that must be given especial attention. Unfortunately, the current state of regulated childcare system either excludes these children all together or doesn't integrate them in a proper, supportive way.

Angela explains that accommodating her autistic son in the mainstream daycare would be beneficial because

"I think my son can learn a lot from kids who are different and they can also learn from him. Like my two sons play and do things together."

This exact point of view is mirrored by Halfon and Friendly (2013), who explain that inclusion is a right of children with special needs and that inclusion benefits not only the children and their families but also the community at large. Despite the fact that inclusion is a human rights issue there is a disheartening trend of exclusion for children with special needs whose parents often find they cannot be accommodated. The Canadian Council on Social Development found that child care options can be frustrating for all parents, “...but for parents of children with disabilities, it can be particularly trying: 16 percent said they had been refused daycare at some point due to their child's disability'” (2006, 32).

Moreover, according to Prentice (2007) poor children with disabilities are even more disadvantaged with research showing the about 20 percent of children from low-income families had been refused care because of their disability, compared with 14 percent of children from higher-income families. Angela, whose autistic son has been turned away by many day care centres, echoes this point of view. Both Prentice’s (2007) findings and Angela’s experience affirm the concept of intersectionality that was discussed in the theoretical frameworks of this MRP. Due to intersectionality of identity, being a child with special needs from a low-income 
family, we see how systems of classism and ableism intersect to further disadvantage children like Angel's son.

Increasingly, in Canada, the debate around early childhood care and education (ECCE) is centred on the public versus private responsibility argument. Childcare advocates argue that a publically funded, national childcare program is in the interest of children, women and society in large and that Canada has a great example in the progress made by countries that offer universal childcare programs. For example, in 2008 The United Nations Children's Fund reported that a national childcare policy with adequate financing is linked to access to high quality early childhood care and education programs and better child development (UNICEF, 2008). The top ranking countries in this report all assume public responsibility for social programs like child care services and included Sweden, Iceland, Denmark, Finland, France and Norway. Additionally, the report linked good ECCE policies to better parental leave, decreased rates of child poverty, and better health outcomes for young children (UNICEF, 2008). These findings have major policy implications for Canada where childcare service policies are fragmented, inconsistent and inadequate.

The discussion around the use of unregulated care is definitely relevant for this research and has both practice and policy implications for social work and other related professions. In this research, I found that three of the four mothers I interviewed have used unregulated care at some point. As presented in the findings, Zeynab, is considering using unregulated care when she goes back to work in the future since she is not optimistic about finding affordable, quality childcare services in her neighbourhood. Knowing about the horrifying news stories of deaths and injuries to children in unregulated care, there is a big need to fill the gap between the childcare spaces available and the number of children who need care. Proponents of universal 
regulated child care services like Friendly (2009; 2013) argue that while some parents might always choose unregulated care over formal childcare service, the current reality is that majority of parents use unregulated care because they have no other options available to them.

The consequences of the use of unregulated childcare have major ethical and professional implications for social work practice. On one hand is social work's commitment and responsibility to ensuring that all children in our society are safe and well cared for. On the other hand, social work cannot ignore the structural and systemic realties of many families who use unregulated childcare and whose options are severely limited. Further social work has to acknowledge the feminization as well as the racialization of poverty, which has a lot to do with why more marginalized families often come in contact with child protection authorities. The racialization of poverty in Canada points out the reality of people of color being disproportionately exposed to poverty. Fro example, research shows that racialized group members are two to three times more likely to be exposed to poverty (Galabuzi, 2005). On a similar note the face of poverty has become increasingly feminine in Canada and well as the global world (Barker, 2009). With women earning less income, owning less property and having their labour force participation limited by patriarchal state policies, more women than men are living in poverty in Canada (Luxton, 2006). These realities of feminization and racialization of poverty are some of the reasons why racialized children and children from single-mother families are over-represented in child protection cases. Social work should recognize these issues of systemic racism and sexism as structural issues that are outside the control of disadvantaged families.

Other advocates view accesses to affordable and quality childcare service as a human rights issue. Framing the discussion around rights communicates the message that women's 
economic advancement as well as children's right to safety and care are non-negotiable especially in a country like Canada where the resources are abundant and available. The social, economic and developmental benefits of quality childcare have been emphasized by academics, child and youth care workers and activists alike. According to Morantz et al (2012 P. 322) "access to high quality childcare services is linked to higher cognitive test scores, improved behavioural development and school achievement, increased employment, lower teenage pregnancy rates, higher socio-economic status and decreased criminal behaviours.” Benefits from accessing quality childcare services are considered even higher for children who come from socially and economically marginalized backgrounds (Nomaguchi, 2006; Morantz et al 2012). From an anti-oppressive social work perspective where dismantling structural systems of oppression is a priority, the finding that some children like those with special needs and those living in poor neighbourhoods, have worse access and quality of care is definitely concerning. Social workers, should engage in advocacy to ensure that all children get safe, high quality care regardless of their needs and their families’ social location.

\section{ii. Caring for Children and other women's work}

In the study, I found that the participant's households are heavily influenced by patriarchal gender norms as far as childcare and other household work is concerned. As

explained by social reproduction theorists introduced in the theoretical frameworks of this MRP, the mothers, like many working mothers in Canada, shouldered all the social reproduction tasks in the family including childcare. This finding is reinforced by much of the literature in the field that shows how women do most if not all the care work in Canadian households in Canada. For example, in Social Reproduction; Feminist Political Economy Challenges Neo-liberalism, 
Luxton (2006) points to the shift of Canadian families from male earner female-carer to dualearner female-carer household, a shift that has oppressed women in a new way. Similarly, Timpson and Prentice (2002) argue that women in Canadian families do most of the caring even though more and more women are joining the labour force in the last few decades. Benzanson and Luxton (2006) explain that women are predominately responsible for maintaining families and caring for them and often face dilemmas in work -life balance that men don’t face.

The structuring of men and women's responsibilities around gender norms is based on patriarchal ideals that are deeply rooted in both Canadian culture and many African cultures. Skinner (2009) explains that the public sentiment around the lower labour force participation of immigrant women is that it is caused by immigrant cultures that are viewed as backward and inherently against women's economic independency. This sentiment ignores the fact that Canadian born women also face barriers to full labour force participation and that immigrant women face extra barriers from discrimination and from Canadian social, economic and immigration policies. While the idea in some of the literature that most immigrant's culture are deeply patriarchal and might restrict women's labour force participation might have some merit, Skinner's (2009) research debunks the 'traditional immigrant' myth by showing that immigrant women are more likely to purchase child care for the purposes of employment than Canadianborn women. Skinner (2009) also shows that when affordable and quality childcare services are provided, as in the case of Sweden's and Quebec, immigrant women's labour force participation increases. As Black feminism espouses, black women, have to deal with systems of oppression that are due to patriarchal cultural norms as well as racist systems and attitudes (Wane, 2004). These racist systems in Canada include the practice of (ref ref). 
Further, research on family dynamics in Canada shows that the patriarchal notion that women are natural car givers is still predominantly present in current Canadian society (Bezanson and Luxton, 2006; Timpson, 2001). As discussed in the theoretical frameworks section this patriarchal notion forms the basis for the social reproduction norms in our society where women, whether or not they work, provide care work for the children, the elderly and the ill. This notion also goes beyond households and effects state policies around childcare, taxation and even immigration. For example, Harder et al (2004) uses the Child Care Expense Deduction (CCED) as a site to examine the gendered and patriarchal assumptions that underlay the Canadian policies around childcare and taxation. The author critiques the concept of "equal earning families" where a dual earning family is taxed the same way a sole earner family that earns the same annual income. Harder et al (2004) argue that neoconservative policies like this ignore issues like class location and social reproduction activities like childcare thereby encouraging a patriarchal ideal of a traditional family where women stay at home and care for children.

Similarly, Bezanson (2006) explains how women are negatively affected when neoliberal states shift responsibility for provisioning public service to the households. After studying the effects of Ontario's conservative government policies of late 1990's, Bezanson (2006) finds that the cost of cutting programs like health care and childcare falls squarely on women whose unpaid labour is almost solely responsible for the social reproduction required by society. Further Bezanson (2006) explains that the interaction of social policies and labour markets creates a context of dual-earner-female-carer model, which greatly disadvantages women. This trend where women must work for their families' survival and yet do all the caring was observed with all the participants in this research. 
Another related issue is experience of low-income mothers, especially those in partnerships opting out of work because of the cost of childcare has been found in several research studies about childcare and labour force participation. For example, Esping Andersen et al. $(2001,71)$ explain that "If, as is typical across much of Europe, the cost of full-time, quality care per child exceeds a third of mothers' expected earnings, the resulting real tax on her employment becomes prohibitive". Further, in a dynamic analysis of the effect of childcare costs on the work decisions of low-income mothers with infants, Baum (2002) examines the relationship between work hours of low-income mothers of infants and access to childcare. Baum (2002) found that childcare costs were a barrier to employment especially for low-income mothers who spent a large percentage of their income on paying for childcare.

Since having a source of income and participating in the labour force is crucial for gender quality and immigrant women's settlement experience it is important to put in place supports to help immigrant women achieve full and enjoyable labour force participation. If immigrant women have to choose between work and family it could lead to isolation and further social and economic marginalization in the communities (Frankowicz, 20007). Moreover, immigrant women's unemployment and underemployment in their younger years leads to further poverty in old age due to lack of adequate pension and supports (Skinner, 2009). However, as I have observed in this research patriarchal gender norms combined with inadequate childcare service is a barrier to immigrant women reaching their full academic and professional potential and realizing their dreams. 


\section{iii. Immigration}

While all the participants in this research have a permanent residency or citizenship status in Canada, there are also several challenges arising from difficulties with the citizenship and immigration systems in Canada. These include inability to sponsor family members and the subsequent lack of family supports as well as lack of credential recognition as in the case of Lisa who was told that none of her university credits from Kenya would be transferred. There are a number of implications for social work research and practice that arise from these findings.

Immigrant women are one of the most marginalized groups in Canada and are over represented in underemployment and unemployment statistics (TIEDI, 2012,). According to Economic Council on women, on average, Immigrant women earn \$ 2000 less than Canadianborn women and \$ 1100 less then immigrant men. In these reports, lack of affordable quality childcare is identified as one of the biggest barrier to employment. In this study we see that even mothers who are able to work and access daycare still struggle with issues around classism and sexism to the extent that they are exhausted and are living day to day at the expense of their dreams. Fiyori, had to put off, for the foreseeable future, her hope to get a nursing education. In the case of Zeynab the lack of quality childcare services cost her employment and forced her to become fully dependant on her husband.

Access to affordable, quality childcare services is inextricably linked to women's equality and economic advancement. Most scholars in this field and advocates of public childcare service agree that having access to affordable, high quality childcare service gives women more employment and economic opportunities (Skinner, 2009; Prentice, 2007; Friendly; 2013; Tyyskä, 2011). Governments and international organisations including the Organisation for Economic Co-operation and Development (OECD) have also emphasized the significance of 
women's labour force participation and economic advancements and the subsequent need to reconcile labour force participation and family life (OECD, 2006; EU, 2011). Even opponents of universal childcare programs like (Richards \& Brzozowski, 2006; Baker et al, 2008; Kottelenberg \& Lehrer, 2013) agree that childcare programs promote more mothers entering in to labour force and that the increased number of workers is economically beneficial.

In this research, I learned about how Lisa and Fiyori could not work while they looked for a childcare service they could afford and how Zeynab stopped working when she was dissatisfied with the kind of care that her son was getting. This finding, coupled with the strong relationship between provision of childcare services and labour force participation, shows that access to childcare should be always be a major focus when fighting for economic and social equality of women. Feminists, most of who, have always advocated for better childcare services, have a responsibility to fight for women's inclusion in the labour force through reliable, affordable and quality childcare service. This fight is even more important in the case of immigrant women who are more likely to live in poverty, be unemployed and be over represented in precarious employment (Skinner, 2009; Bushnik, 2006;). Further, immigrant women have less family supports and often face other systemic issues like discrimination and lack of credential recognition (Frankowicz, 2007). This understanding of the intersectional experience of immigrant women is particularly important for practitioners and scholars coming from anti-oppressive and third wave feminist framework. 


\section{Conclusion}

Access to high quality, affordable childcare service is important for both child development and women's labour force participation. Immigrant women in particular need employment not only for economic reason but also for cultivating a sense of belonging in their new communities. The women I spoke to all needed to childcare services before they could work, volunteer or go back to school. Despite the presence of their partners and children's fathers in their lives these women still had to shoulder almost all the responsibility for care of their children. Moreover, the women have lost crucial extended family supports since immigrating for better economic and live opportunities.

In this MRP I not only gained a better understanding of the systemic and daily challenges that this women face, but also of their resourcefulness, hard work and motivations. While all the women had aspects of the childcare services that they were dissatisfied with, they still expressed gratitude for the opportunity to get some help even if it was not enough help. Some of the mothers also expressed hope that their children will not struggle as much as they are doing and that their children's success will make their struggle worth it. One way to make this wish come true is to provide better quality affordable childcare for all mothers to be able to work, since research shows that a working parent is one of the most important ways to reduce intergenerational poverty in families (Richards \& Brzozowski, 2006). However, if mothers continue to struggle under the weight of their many responsibility or are forced to choose between quality and cost of care, they could continue to live in poverty and lose any chance of securing a better future for the children.

In this study, I was able to highlight some of the major gaps in the state of childcare service in Canada and particularly in Ontario. The lack of a publically funded national child care 
plan has led to issues like inadequate spaces, poor quality services and lower inclusion rates of children with special needs. This research also found that difficulties with the immigration system and patriarchal gender norms further complicate the life-work balance of the mothers who participated in the study.

As stated in my methodology section, this study's major limitation is the short time frame, which did not allow for the chance to include the voices of more mothers. The short time frame also affected my ability to recruit from community organizations since the process to get permission requires more time than I had available. Additionally, after transcribing the interviews I got the sense that my research would have benefited from a second more in-depth interview with the participants. In the second interviews the participants could talk in-depth about their feelings towards bearing all the burden of the housework and putting their dreams on hold to work preciously for survival. Unfortunately, this was impossible because of the fact that the participants have only committed to one interview and that I did not have the time required to re-do an ethics application and materials for my research.

Given the scarcity of immigrant women and African immigrant women's voices in the childcare literature available, more research in this subject will be beneficial for the field. Future research on a larger scale could allow for more time and more participants to share their experiences. It would be interesting to have research from feminist perspective focusing on how the women see their role in their families and if they foresee any changes in the gender dynamics of their households as well as in the future households of their children. Despite the limitations, my hope is that this study will fill a small gap by adding to the limited literature on immigrant women's views on childcare access and experiences. It is also my hope that my research will open doors for further research with this population and around the topics explored in this MRP. 


\section{Appendices}

\section{Appendix A - Interview Guide Questions}

The interview for this study was conducted in a Narrative style and will involve a conversation between the investigator and the participant. However, the following questions were used to focus the interview on issues around the topic of this research.

At the beginning of the interview participants will be told that they can refuse to answer any question or stop the conversation at any point.

1) Are you currently using formal childcare services? Or did you use it before?

2) How many children do/did you in have in formal daycare/child care settings?

3) Do you have other children? If so how many?

4) Who usually arranges for childcare services in your household (e.g. making applications for care and dealing with childcare service providers)?

5) Do you have extended family living in Toronto?

6) Do you work fulltime or part-time? How many hours a week do you work?

7) Do you think your current childcare access arrangement affects your work? If so how?

8) Tell me about your experiences using formal childcare in Toronto?

9) Do you think you that being an African woman makes your experiences with accessing childcare services different? Why? Why not?

10) Do you think you that being an immigrant woman make your experiences with accessing childcare different? Why? Why not?

11) Tell me about your most memorable experience related to childcare while you were living in Toronto? 


\section{Appendix B -Information and consent form}

\section{Information letter and Consent Form Ethics Review of Research Involving Human Subjects}

You are being asked to participate in a research study. Before you give your consent to be a volunteer, it is important that you read the following information and ask as many questions as necessary to be sure you understand what you will be asked to do.

Study Title: How do Working African-Immigrant Mothers Experience Formal Childcare Services in Toronto?

Investigators: Muno Osman, Masters in Social Work Candidate. Ryerson University Supervisor: Dr Henry Parada, Graduate Program Director and Associate Director. Ryerson University

Purpose of the Study: The researcher in this study will look at the experiences of African immigrant mothers who are currently using or have used formal childcare in Toronto while they work. The researcher is interested in exploring working African Immigrant mothers' experiences relating to formal childcare access in Toronto.

\section{Description of the Study:}

The researcher will share the study's flyer on social media and public community spaces. The flyer includes a brief description of the study and my contact information. Once you get the flyer you can contact the researcher if you decide wish to participate or have any questions about the study. The following procedure will be followed once you decide to be part of the study.

i. You and I will agree on a time and a place to meet. I am flexible about the time and place for meeting and the options include; private rooms in community centres, Toronto public libraries and Ryerson University library. While I prefer to do interviews at these locations I am also open to doing the interviews at home if you do not want to or cannot meet me at those public locations. In addition telephone interviews can be arranged if a face-to face meeting is not possible.

ii. The interview is expected to last 1 to 1.5 hours.

iii. The Interview will be audio taped (if you agree) and I also will take some notes during the conversation.

iv. After transcribing the interview I will contact you [should you wish] one more time to confirm that the information in the transcript is ok with you. This can be done over the phone or another face-to-face meeting can be arranged if you prefer.

Risks or Discomforts: Risks and discomforts anticipated by the researcher are: 
Risk: Mothers participating in the study might worry about their privacy.

Risk Management: Investigator will respect participant's privacy and confidentiality. This means your identity will remains confidential and no information that may identify you will be included in the final thesis or subsequent publications. Confidentiality will only be broken if you inform me of a real or potential harm to someone else.

Risk: Taking time away from mothers’ busy schedules

Risk management: I will be flexible about the time and place of meetings and will also respect your time by starting and ending interviews on time.

Benefits of the Study: The study will give you an opportunity to talk about your experiences of accessing formal childcare as a working African immigrant mother. The study is expected to add our communities' voices to the literature on Childcare in Toronto as well as Canada. This study might also inform future research that can help change childcare policies and programs in Toronto/Canada. However, I cannot guarantee you will gain any direct benefits from participating in the study.

Confidentiality: To respect confidentiality the study will use pseudonyms (fake names) instead of your real name. The consent forms and other forms that might include the real names of research participants will be stored separately from the other research materials. You will have the choice of hearing the interview and reading the transcript so as to remove any information you don't wish to be included in the study. As the researcher I will keep everything you tell me confidential unless you tell me something about someone else being harmed or being at risk of harm. If this happens I will speak to you about why I cannot keep that information confidential and we can discuss next steps. All data and information from this study will be stored in my password protected computer location and will only be accessed by myself and my supervisor who is also named on this consent form. All the data, including audio-records of the interview, transcripts and all other information will be destroyed two years from the date of signing this consent form. This date is estimated to be between; March 15, 2016 to May 30, 2016.

Incentives to Participate: You will not be paid to participate in this study. The researcher appreciates you sharing your story and experiences and hopes that these stories will add valuable insights to the current literature on formal child care services in Toronto. The investigator hopes that this research can add the voices and opinions of working African Immigrant mothers to the mainstream literature on child care services.

Costs and/or Compensation for Participation: Since there might be cost associated with travelling to and from interviews I will be flexible about when and where to meet you. I am also offering two TTC tokens if you need to use them on the day of the interview.

Voluntary Nature of Participation: Participation in this study is voluntary. Your choice of whether or not to participate will not influence your future relations with Ryerson University or the researcher or community. If you decide to participate, you are free to withdraw your consent 
and to stop your participation at any time without any negative consequence or loss of benefits. At any particular point in the study, you may refuse to answer any particular question or stop participation altogether.

Questions about the Study: If you have any questions about the research now, please ask. If you have questions later about the research you may contact the supervisor of this study.

\title{
Henry Parada
}

Graduate Program Director and Associate Professor

4169795000 ext. 6223

hparada@ryerson.ca

This study has been reviewed by the Ryerson University Research Ethics Board. If you have questions regarding your rights as a research participant in this study, please contact:

\author{
Toni Fletcher, Research Ethics Coordinator \\ Research Ethics Board \\ Office of the Vice President, Research and Innovation \\ Ryerson University \\ 350 Victoria Street \\ Toronto, Ontario M5B 2K3 \\ 416-979-5042 or toni.fletcher@ryerson.ca
}

\section{Agreement:}

Your signature below indicates that you have read the information in this agreement and have had a chance to ask any questions you have about the study. Your signature also indicates that you agree to be in the study and have been told that you can change your mind and withdraw your consent to participate at any time. You have been given a copy of this agreement.

You have been told that by signing this consent agreement you are not giving up any of your legal rights.

Name of Participant (please print)

Signature of Participant

Date

Signature of Investigator

Date 
In order to make sure that the data collected is accurate, I would like to audio record the interviews. Your signature here shows that you aware of and agree that the interview is being audio taped. Only the investigator and the supervisor named on this agreement will be able to listen to the audio.

Signature of Participant

Date

You can still participate in this study if you don't wish to have this interview audiotaped. Your signature here indicates that you have declined to have the interview audio-taped.

v. Signature of participant

Date 


\section{REFERENCE LIST}

Albanese, P. (2006). Small town, big benefits: The ripple effect of $\$ 7 /$ day child care*. The Canadian Review of Sociology and Anthropology, 43(2), 125-140.

Albanese, P., Rauhala, A., Ferns, C., Johnstone, J., Lam, J., \& Atack, E. (2010). Hiding the elephant: Child care coverage in four daily newspapers. Journal of Comparative Family Studies, 41(5), 817-XVII.

Armstrong, P. (1990). In Armstrong H. (Ed.), Theorizing women's work. Toronto, Canada: Garamond Press.

Armstrong, P. (1994). In Armstrong H. (Ed.), The double ghetto: Canadian women and their segregated work (3rd ed. ed.). Toronto: McClelland \& Stewart.

Baker, M. (2009). Working their way out of poverty? Gendered employment in three welfare states*. Journal of Comparative Family Studies, 40(4), 617-XI.

BUSHNIK, T. 2006. Child care in Canada: Research paper. Children and Youth Research Paper Series. Ottawa: Statistics Canada.

Caldwell, B. M. (1998, May 1998). Child care for children with disabilities. The Exceptional Parent, 28, 81.

CANADIAN COUNCIL ON SOCIAL DEVELOPMENT. 2006. The progress of Canada's children and youth. Ottawa: Canadian Council on Social Development 
Child Care Facts in Ontario, retrieved

from: http://www.hdsb.ca/Programs/KindergartenProgram/Documents/Child\%20Care\%20i n\%20Ontario\%20-\%20Key\%20Facts.pdf. Retrieved on August 11, 2014.

Cleveland, G., Forer, B., Hyatt, D, Japel, C, \& Krashinsky, M. (2008). New evidence about child care in Canada: Use patterns, affordability and quality. IRPP Choices, 14(2). Montreal: Institute for Research on Public Policy

Collins, P. (2000). Gender, black feminism, and black political economy. The Annals of the American Academy of Political and Social Science, 568(1), 41-53.

Collins, P. H. (2000). Black feminist thought: Knowledge, consciousness and the politics of empowerment. London, GBR: Routledge.

Creswell, J. W. (2009). Research design: Qualitative, quantitative, and mixed methods approaches (3rd ed. ed.). Thousand Oaks, Calif.: Sage Publications.

Davis, K. (2008) "Intersectionality as buzzword: a sociology of science perspective on what makes a feminist theory successful", Feminist Theory, Vol.9 No.1 pp67-85

Edwards, P. (2013). Day Care by the Numbers. Retrieved from; The Childcare Resource and Research Unit. Retrieved on: March 23, 2014. http://www.childcarecanada.org/search/apachesolr_search/feb\%206

Frankowicz, A. (2007). In Ryerson University. School of Graduate Studies. Program in Immigration and Settlement Studies. (Ed.), Networking care: Immigrant women's access to childcare 
Fraser, H. (2004). Doing narrative research. Qualitative Social Work, 3(2), 179-201.

Friendly, 2014. Childcare’s rough ride. Retrieved from: http://www.childcarecanada.org/blog/child-care\%E2\%80\%99s-rough-ride. Retrieved on: May 25, 2014.

Friendly, M \& Ferns, C. (2014) Another February 6: One more year -- and whaddya get? (Not more and better child care). Retrieved from; The Childcare Resource and Research Unit. Retrieved on: March 23, 2014. http://www.childcarecanada.org/documents/research-policypractice/14/02/another-february-6-one-more-year-and-whaddya-get-not-more-a

Friendly, M. (2009). In Prentice S. (Ed.), About Canada: Childcare. Black Point, NS: Fernwood Pub.

Friendly, M., \& Hennessy, T. (2012). The path to better child care in Ontario Canadian Centre for Policy Alternatives.

Galabuzi, G. 2005. The Racialization of Poverty in Canada: Implications for Section 15 Charter protection. The National Anti-Racism Council of Canada National Conference, Ottawa.

Halfon, S., \& Friendly, M. (2013). Inclusion of young children with disabilities in regulated childcare in Canada: A snapshot: Research, policy and practice. (). Toronto, ON, CAN: Childcare Resource and Research Unit.

Harder, L., Mircea, G., Mihai, C., Pereboom, L., Swartz, D., Groves, E., Keating, K. (2004). Child care, taxation and normative commitments: Excavating the child care expense deduction debate. Studies in Political Economy, 73 
Hill Collins, P. (1990) Black Feminist Thought: Knowledge, Consciousness and the Politics of Empowerment, Options

Hoffman, J. (2010, Apr 2010). Child care DO YOU GET WHAT YOU PAY FOR? Today's Parent, 27, 86-91.

Humphrey, C. (2007). Insider-outsider. Action Research, 5(1), 11-26.

JAPEL, C., R. TREMBLAY, \& S. COTE.2005. Quality counts! Assessing the quality of daycare services based on the Quebec longitudinal study of child development. IRPP Choices 11 (5): 342

Kottelenberg, M. J., \& Lehrer, S. F. (2013). New evidence on the impacts of access to and attending universal child-care in Canada. Canadian Public Policy, 39(2), 263-286.

Kwok, S \& Wallis, M. A. (2008). Daily struggles: The deepening racialization and feminization of poverty in Canada

Lefebvre, P., \& Merrigan, P. (2005). Low-fee (\$5/day/child) regulated childcare policy and the labor supply of mothers with young children: A natural experiment from Canada. Rochester, Rochester:

Morantz, G., Rousseau, C., Banerji, A., Martin, C., \& Heymann, J. (2013). Resettlement challenges faced by refugee claimant families in montreal: Lack of access to child care. Child \& Family Social Work, 18(3), 318-328. 
N omaguchi, K. e. M. (2006). Maternal employment, non-parental care, mother-child interactions, and child outcomes during preschool years. Journal of Marriage and Family, 68(5), 1341-1369.

Norwood, C. (2013). Perspective in Africana Feminism; Exploring Expressions of Black Feminism/Womanism in the African Diaspora. Sociology Compass. 7(3), 225-236.

OECD (2006) Starting strongII. Early childhood education and care, Paris: OECD.

Penn, H. (2012). Childcare markets: Do they work? (). Toronto, ON, CAN: Childcare Resource and Research Unit.

Prentice, S. (2007). Less access, worse quality. Journal of Children and Poverty, 13(1), 57-73.

Razak, N. (2002). Transforming the field: Anti-racist and anti-oppressive perspectives for the human service practicum. Winnipeg, MB, CAN: Fernwood Publishing.

Research as resistance: Critical, indigenous and anti- oppressive approaches (2005). In Brown L. A., Strega S. (Eds.), Toronto: Canadian Scholars' Press.

Richards, J., \& Brzozowski, M. (2006). Let's walk before we run: Cautionary advice on childcare. (). Toronto, ON, CAN: C.D. Howe Institute.

Saulnier, C. F. (2000). Incorporating feminist theory into social work practice: Group work examples. Social Work with Groups, 23(1), 5-29.

Schwandt, T. A. (2007). The Sage dictionary of qualitative inquiry (3rd Ed.). Thousand Oaks, CA: Sage Publications. 
Skinner, S. (2008). Who has autonomy? the impact of immigration, gender and welfare state policy on the lives of immigrant women. (M.A., Concordia University (Canada)). ProQuest Dissertations and Theses, (304477740).

Tyyskä V (2011). Women, Citizenship and Canadian Child Care Policy in the 1990s. Occasional paper, Childcare Resource and Research Unit. Retrieved from: http://www.childcarecanada.org//publications/occasional-paper-series/01/03/womencitizenship-and-canadian-child-care-policy-1990s. Retrieved on April 29, 2014.

Ungerson, C. (1983). Why do women care? In Janet Finch (ed). A labor of love - Women, Work and Caring; London. 13-50.

UNICEF. (2008). The child care transition, Innocenti Report Card 8, 2008. Florence: UNICEF Innocenti Research Centre.

Up close and personal: The teaching and learning of narrative research (2003). In Josselson R., Lieblich A. and McAdams D. P. (Eds.), (1st ed. Ed.). Washington, D.C.: American Psychological Association.

Van de Sande, A. (2011). In Schwartz K. (Ed.), Research for social justice: A community-based approach. Black Point, N.S.: Fernwood Pub.

Wane, N. N. (2004). Black canadian feminist thought: Tensions and possibilities. Canadian Woman Studies, 23(2), 145-153.

We're rooted here and they can't pull us up: Essays in African Canadian women's history (1994). In Bristow P. (Ed.), .Toronto, ON, CAN: University of Toronto Press. 